\title{
Reese-Ellsworth Classification IA
}

National Cancer Institute

\section{Source}

National Cancer Institute. Reese-Ellsworth Classification IA. NCI Thesaurus. Code C123368.

Solitary tumor, smaller than 4 disc diameters, tumor at or behind the equator. 